\title{
ESTIMATES OF HERITABILITY AND CORRELATION FOR MILK AND GROWTH TRAITS IN ZARAIBI GOAT
}

\author{
I. Shaat ${ }^{1}$, M. Mabrouk ${ }^{2}$, A. A. Raheem ${ }^{1}$ and A. Hamed ${ }^{1}$ \\ 1- Sheep \& Goats Research Department, Animal Production Research Institute, \\ Agriculture Research Center, Nadi El-Said St., Dokki, Cairo, Egypt, 2- Animal \\ Production Department, Faculty of Agriculture, Al-Azhar University
}

\section{SUMMARY}

Records from the El-Serw research station belonging to Animal Production Research Institute were used to estimate the genetic parameters for the economically most important milk and growth traits in the Zaraibi goat breed. There were 99 and 110 half-sib families over the periods 1995-2003 and 1990-2003 for milk and growth traits, respectively. Milk traits were, milk yield during the first 90 days and the total yield and the length of lactation period. The weight was recorded at birth, 90, 180 and 365 days of age. Mixed model methodology based on a multi-trait animal model was used to estimate the genetic and phenotypic parameters. A repeatability model was used for milk traits. Heritability for milk yield was 0.27 (90 days) and 0.35 (total) with a genetic correlation of 0.89 between them. The lactation period had heritability 0.15 and it was naturally positively correlated with yield, especially with the total yield (0.80). Therefore a selection program on the earlier 90 days yield record would give the best annual genetic changes for milk traits. The heritability for weight traits varied between 0.12 and 0.33 with high (0.42-0.82) positive genetic correlations between them. The pre-weaning gain (from birth to 90 days) is a very useful tool for selection, as it has a satisfactory heritability (0.33), it is very highly correlated with the post-weaning gain (from weaning to 6 months) and it is available well before any selection decisions are made.

Keywords: Multiple traits, animal model, genetic parameters, growth and milk production traits, Zaraibi goat

\section{INTRODUCTION}

Goats are an important source of meat in Egypt. One of the better known native breeds is Zaraibi goat, also called Egyptian Nubian. Although, the population size is small ( $2 \%$ of the total goat population in Egypt), the breed has a good reputation in Egypt and the Near East region, because of its high prolificacy and milk production (Galal et al., 2005). Some authors reported this breed to be a progenitor for the standard international Anglo-Nubian breed (Devendra and McLeroy, 1982 and Gall, 1981).

The aim of this study was to estimate the genetic and phenotypic parameters for economically the most important milk and growth traits for using these estimates in developing a selection programme for the Zaraibi goats.

Issued by The Egyptian Society of Animal Production 


\section{MATERIALS AND METHODS}

\section{Breed characterization}

Zaraibi goat is a promising goat breed in Egypt. At present the breed mainly exists in the North East of the Nile Delta. Some animals could be found as household goats in the north-eastern Delta, kept as a hobby rather than productive flocks. The breed is also called Nubian or Nubi, after Nuba in Upper Egypt. It is hard to find these goats now in southern Egypt. The total population for the breed is about 56,000 head and the breed is considered to be at risk (Galal et al., 2005). The body is long and deep with long legs. The average body length, height at withers and heart girth in females is 70.4, 69.4 and $73.3 \mathrm{~cm}$, respectively (Abdel-Monaam, 1986). The head is big and it has a distinctive convex profile with a Roman nose and with many animals having an undershot jaw. Animal of either sex rarely has horns. The ears are broad, long, pendulous and drooping, sometimes with a fold at the tip', especially in young kids. Body color is very variable from cream to red, black, brown or mixture of these and sometimes with white spots. The body is covered with short hair (Galal et al., 2005).

\section{Herd management}

This study was carried out on the Zaraibi goat herd kept at El-Serw experimental station located in the north-eastern part of the Nile Delta. The research station belongs to the Animal Production Research Institute of Agriculture Research Center at the Ministry of Agriculture. Animals were housed in semi-open pens and fed on Egyptian clover (Trifolum alexandrinum) from December to May. For the rest of the year they fed on rice straw and green fodder, if available, as an addition to concentrate mixture.

The composition of the concentrate mixture was cotton seed cake, maize, wheat barn, rice barn, calcium carbonate and sodium chloride with an average composition of $16 \%$ crude protein, $3 \%$ crude fat and $15 \%$ crude fiber on average. Does were supplemented with half a kilogram concentrate mixture per day for two weeks before the mating season and from the second to the fourth week of pregnancy. Moreover, milking goats were supplemented with one $\mathrm{kg}$ of concentrate mixture daily. Water is offered twice a day in early morning and late afternoon.

There was one mating season per year (October) from year 1990 until 1992 and starting from year 1993, the herd was divided into two groups for two mating seasons per year (June and October). Does were randomly divided into mating groups of 3035 does and each was randomly assigned to a fertile buck. Mating period lasted for 45 days. Does were first joined with the buck at the age of approximately 18 months. At kidding, newborns were identified and their type of birth, gender and pedigree were recorded. Weight was recorded within twenty-four hours after birth and then at 30-day intervals. Kids were weaned at approximately 90 days of age.

\section{Data}

3.1. Milk production traits: A total of 2363 lactation records obtained from 975 does, progeny of 99 sires and 571 dams were used in this study. Data were collected from October 1995 to October 2003. Milk production traits were measured as total milk yield (TMY), milk yield up to 90 days (MY90) and lactation period (LP). Milk production of does was recorded daily after kidding until drying off. Morning milk 
yield was measured during the suckling period by isolating kids from their dams at $5.00 \mathrm{pm}$ and then weighed on the following morning at $8.00 \mathrm{am}$, and allowed to suckle their dams until satisfaction, the increase in kids weight after each suckling was considered as their milk consumption. The does were hand milked in order to estimate residual milk (stripped milk). The sum of suckled and stripped milk represents the quantity of the morning milk yield. Similar procedure was followed in estimating the evening milk production. The sum of morning and evening milk production represented daily milk production.

After weaning, does were machine milked twice a day at 8.00 am and at $5.00 \mathrm{pm}$. Does were considered dry when their daily milk yield dropped to $100 \mathrm{~g}$ a day.

Milk yield up to 90 days was calculated by summing daily milk yield up to 90 days after kidding. Total milk yield was calculated as the sum of milk during suckling period and milking period. The lactation period was the interval between kidding date and drying off date.

3.2. Growth traits: Data were collected on 6755 Zaraibi kids progeny of 110 sires and 1331 dams, during the period from 1990-2003.

Six body weight traits were measured in this study, weight at birth (WB), 90 days (W90-D), 180 days (W180-D), 365 days (W365-D), pre-weaning (PRW) and postweaning daily gain (PSW). Weight at birth was recorded within 24 hours after kidding. Kids were kept with their dams all the time until weaning. Weaning weight was recorded at 90 days of age. Kids were weighed monthly after kidding till 18 months of age. Weights were adjusted to 90, 180 and 365 days of age by intrapolating linearly the recorded weight to the weight of the designated age.

Pre-weaning daily gain $(\mathrm{g} / \mathrm{d})$ was calculated as the difference between birth weight and live weight at 90 days of age (weaning weight) divided by number of days from birth up to weaning while, post weaning daily gain $(\mathrm{g} / \mathrm{d})$ was calculated from the difference between weaning weight at 90 days and live weight at 180 days divided by number of days from weaning up to 180 days of age.

\section{Statistical analysis}

(Co)variance components for the traits were estimated with a multi-trait analysis using the models described in Table 1. A derivative-free REML algorithm (DFREML, Graser et al., 1987) using computer program of Boldman et al. (1995) was used to estimate (co)variance components. Local convergence was considered attained when the variance of the $-2 \log$ likelihood in the simplex was less than $10^{-6}$. Global convergence was considered attained when the -2 log likelihood did not change to the third decimal after restarting.

4.1. Milk production traits: The fixed effects on milk production traits included in the model were litter size (single, twins and triplets or more), season of kidding (winter and autumn), doe parity (1, 2, 3, 4, 5, 6 and 7) and year of kidding (1995, $1996, . .2003$ )

The assumed model was:

Where,

$$
\mathrm{Y}=\mathrm{X} \beta+\mathrm{Z}_{\mathrm{a}} \mathrm{a}+\mathrm{Z}_{\mathrm{c}} \mathrm{c}+\mathrm{e} \quad(\text { Model 1) }
$$

$\mathrm{Y}$ is vector of observations;

$\mathrm{X}$ the incidence matrix for fixed effects; 
$\beta \quad$ the vector of an overall mean and fixed effects of litter size, season of kidding, doe parity and year of kidding

$\mathrm{Z} \quad$ the incidence matrix for random effects;

a the vector of additive genetic effect;

c the vector of permanent environmental effect ; and

e the vector of random errors $\sim \mathrm{N}\left(0, \mathrm{I} \sigma_{\mathrm{e}}^{2}\right)$ where I is identity matrix and the residual variance is $\sigma_{\mathrm{e}}^{2}$.

4.2. Growth traits: The fixed effects on growth traits were type of birth (single, twins, triplets or more), gender (male and female), age of doe at kidding $(\leq 24,>24$ $36,>36-48,>48-60$ and $>60$ months) and year-season of birth $(1,2,3, \ldots . .25)$.

The assumed model was:

Where,

$$
\mathrm{Y}=\mathrm{X} \beta+\mathrm{Za}+\mathrm{e} \quad(\text { Model 2) }
$$

$\mathrm{Y}$ the vector of observations;

$\mathrm{X}$ the incidence matrix for fixed effects;

$\beta$ the vector of an overall mean and fixed effects of type of birth, gender of kids, age of doe and year-season of birth;

$\mathrm{Z}$ the incidence matrix for random effect ( additive genetic effect);

a the vector of additive genetic effect; and

e the vector of random errors $\sim \mathrm{N}\left(0, \mathrm{I} \sigma_{\mathrm{e}}^{2}\right)$ where $\mathrm{I}$ is identity matrix and the residual variance is $\sigma^{2}$.

Table 1. Description of fixed and random effects in animal models for milk and growth traits

\begin{tabular}{lcc}
\hline Traits & Fixed Effects & Random Effects \\
\hline Milk traits & $\begin{array}{c}\text { Litter size, Parity number, } \\
\text { Season of kidding, Year of kidding }\end{array}$ & $\begin{array}{c}\text { Animal additive genetic (doe) } \\
\text { Permanent environmental (doe) }\end{array}$ \\
Growth traits & $\begin{array}{c}\text { Age of dam, Gender of kid, } \\
\text { Type of birth, Year-season of birth }\end{array}$ & Animal additive genetic (kid) \\
\hline
\end{tabular}

\section{RESULTS AND DISCUSSIONS}

\section{Milk production traits}

The overall mean of TMY was $263.0 \mathrm{~kg}, 135.8 \mathrm{~kg}$ for MY90 and 262 days for LP. Estimates of additive genetic and permanent environmental variance for milk production traits are shown in 2.

Table 2. Estimates of heritability (on diagonal), genetic correlations (above diagonal) and phenotypic correlations (below diagonal) for TMY, MY90 and LP

\begin{tabular}{lccc}
\hline Traits & TMY & MY90 & LP \\
\hline TMY & $\mathbf{0 . 3 5}$ & 0.89 & 0.80 \\
MY90 & 0.67 & $\mathbf{0 . 2 7}$ & 0.46 \\
LP & 0.70 & 0.14 & $\mathbf{0 . 1 5}$ \\
\hline Additive genetic variance & 2045.12 & 284.45 & 582.89 \\
Environmental variance & 4258.30 & 886.88 & 3148.19 \\
\hline
\end{tabular}


1.1. Heritability: Heritability estimates for milk production traits are presented in Table 2. The results showed that heritability was moderate for milk yield traits but low for lactation period (Table 2). Heritability estimate obtained in this study for total milk yield (0.35) is higher than the finding of Abdel-Raheem (1998) who worked on a part of the data used in the present study and reported a value of 0.10 . Moreover, other authors working on various breeds of goat have found different estimates being $0.14,0.29,0.18$ and 0.24 reported by Kominakis et al. (2000) for Skopelos goat; Eissa (1996) on Damascus goat; Analla et al. (1995) for Granadina goat and Rabasco et al. (1993) for Verata goat, respectively. However, Grossman et al. (1986) reported higher estimates of heritability for total milk yield in Alpine, LaMancha, Nubian, Saanen, and Toggenburg goat breeds and gave figures $0.42,0.38,0.45,0.44$ and 0.41 , respectively.

Estimate of heritability for milk yield for MY90 in this study (0.27) is in the neighborhood of the estimate of 0.29 reported by Constantinou and Mavrogenis (1987) for Damascus goats. While it is lower than that reported by Constantinou et al. (1985) of 0.35 for Damascus goats. Abdel-Raheem (1998) and El-Saied et al. (1998) reported lower estimates of heritability (0.03 and 0.02$)$ for lactation period than that obtained in the present study $(0.15)$. However, higher estimates were reported by Eissa (1996) for Damascus and Barki goats of 0.25 and 0.20 , respectively.

The high estimates of heritability for milk yield traits obtained in this study indicate that the procedure used to measure the yield is accurate enough, especially early measurement done with the suckling kids gives also satisfactory results in this respect and it could be used as a criterion in an effective selection program.

1.2. Repeatability: The same pattern was found for the repeatability estimates for milk yield traits as that for heritability. The estimate of repeatability for total milk yield was 0.43 , which is close to those published by Grossman et al. (1986) of 0.44 in Saanen goat and Iloeje et al. (1981) of 0.42 in Toggenburg goat.

Our estimates are higher than $0.29,0.32$ and 0.20 obtained by Portolano et al. (2001) with Barbaresca goat; Mourad (2001) with Alpine goat and Abdel-Raheem (1998) with Zaraibi goat, respectively.

Estimate of repeatability for milk yield up to 90 days found in this study (0.33) was lower than 0.49 calculated by Constantinou (1989) in Damascus goat. Furthermore, repeatability estimate for lactation period in the present study of 0.22 , is similar to those reported by Eissa (1996) in Barki goat and Carcia (1985) in Criallo crossbred goats but higher than 0.05 reported by Abdel-Raheem (1998) on Zaraibi goat and lower than 0.72 and 0.29 reported by Mourad (2001) on Alpine goat and Portolano et al. (2001) on Barbaresca goat.

The obtained repeatability values speak for the satisfactory accuracy of milk yield records, as stated in the context of heritability estimation.

1.3. Genetic and phenotypic correlations: The genetic and phenotypic correlations between milk production traits are shown in Table 2. Results of genetic correlation show high and positive estimates especially between TMY and both MY90 and LP (0.89 and 0.80). These estimates are close to those reported by Portolano et al. (2001) and Kominakis et al. (2000). In contrast, the genetic correlation between MY90 and LP was moderate (0.46). As the correlation was much higher with the total milk yield and LP, this implies there is also genetic variation for the shape of lactation 
curve in Zaraibi goats, in the same way as found in dairy cattle (Lidauar et al, 2003). Hence before an efficient selection program benefiting from an early indicator of 90 days milk yield is established, some information is needed on the variation in lactation curves. When several records per lactation are available, even test-day model evaluation exploiting all the different records and producing estimates for the shape of lactation curve and very early predictors for the total milk yield can be considered (Lidauar et al., 2003).

Phenotypic correlations between milk production traits were moderate (Table 2) and show the same trend as for the genetic correlations. There was a low phenotypic correlation between MY90 and LP being 0.14, not surprising after was found for the genetic one. The explanations and implications would be the same as discussed on the genetic correlation.

\section{Growth traits}

The overall means for studied growth traits were 2.0, 10.7, 16.0 and $24.2 \mathrm{~kg}$ for WB, W90-D, W180-D and W365-D, respectively and 96.8 and $60.0 \mathrm{~g} / \mathrm{d}$ for PRW and PSW, respectively.

2.1. Heritability: Heritability estimate of body weight and weight gain decreased over age (Table 3 ). Heritability estimates for all studied weight traits are lower than those reported for the same herd by Shaat et al. (2005) and Mekkawy (2000) or breeds like Black Bengal and Jamnapari goats (Singh, 1997) and Angora goats (Hermiz et al., 1997).

Table 3. Estimates of heritability (on diagonal), genetic correlations (above diagonal) and phenotypic correlations (below diagonal) for Zaraibi growth traits

\begin{tabular}{lcccccc}
\hline Traits & WB & W90-D & W180-D & W365-D & PRW & PSW \\
\hline WB & $\mathbf{0 . 2 1}$ & 0.42 & 0.47 & 0.62 & 0.18 & 0.10 \\
W90-D & 0.13 & $\mathbf{0 . 1 6}$ & 0.77 & 0.82 & 0.47 & 0.33 \\
W180-D & 0.21 & 0.59 & $\mathbf{0 . 1 2}$ & 0.77 & 0.41 & 0.29 \\
W365-D & 0.25 & 0.50 & 0.62 & $\mathbf{0 . 1 2}$ & 0.40 & 0.26 \\
PRW & 0.11 & 0.37 & 0.29 & 0.33 & $\mathbf{0 . 3 3}$ & 0.99 \\
PSW & 0.11 & 0.02 & 0.30 & 0.32 & 0.99 & $\mathbf{0 . 2 8}$ \\
\hline Additive genetic variance & 0.06 & 0.85 & 0.78 & 0.78 & 0.09 & 0.03 \\
Environmental variance & 0.21 & 4.53 & 5.75 & 5.83 & 0.17 & 0.07 \\
\hline
\end{tabular}

The differences in heritability estimates could be due to the different methods used for the estimation and the population sampled. A preliminary analysis of the present data used in this study showed that the single trait analysis using MTDFREML programme resulted in higher estimates of heritability than when using the multi trait analysis. On the other hand, the heritability estimates for daily gain traits obtained in this study (Table 3) are higher than those reported by Singh (1997) 
with Black Bengal; Bata (1989) with Zaraibi and Mavrogenis et al. (1984) with Damascus goats.

However, they are lower than the figures given by Al-Shorepy et al. (2002) with Emirati goats. The gain traits are more important in selection and the results are indicating that the research station data would be sufficient for carrying out an efficient genetic improvement scheme in the economically important meat production trait.

\subsection{Genetic and phenotypic correlations:}

There are strong positive genetic correlations between weight traits (W90-D, W180-D, and W360-D). The genetic correlation was moderate between weights at birth (WB) and later age (Table 3). Possibly the dam is more important in determining the birth weight than the animal itself. The present findings are in good agreement with those for Zaraibi (Shaat et al., 2005; Mekkawy 2000), Common African x Alpine (Mourad and Anous 1991) and Black Bengal goats (Singh 1997). Phenotypic correlations for weight traits (Table 3) ranged from low to medium according to the age, while it was high (0.99) between the daily gain traits (PRW and PSW).

The strong positive genetic correlation $(0.99)$ between the daily gain traits indicate that genes responsible for the phenotypic expression of pre-weaning daily gain were also responsible for expression of post-weaning daily gain. Therefore, selection for the PRW trait will improve the PSW trait as well and selection can be made at an early stage of age.

\section{CONCLUSIONS}

The research station herd proved to provide a satisfactory body of data for estimating the genetic parameters. The obtained results are in agreement with earlier studies in Zaraibi goat and with those found in other goat breeds. We were not able to present the standard errors for the estimates. However, as the number of half-sib families for both the traits was close to one hundred and the obtained values were from moderate to high, then e.g. the standard error of the heritability estimate for growth traits would be very small indeed, of the order $10^{-3}$ (Falconer and Mackay, 1996).

Meat production is economically the most important trait in Zaraibi goats and therefore the first priority in genetic improvement program is to construct an efficient selection scheme for the trait. The most feasible scheme would be to base the information flow and the operations within few herds. The relatively cheap measurements routines used in a few herd research stations seem to be sufficient to reveal the genetic differences between animals. When the operations are done in few production environments, the management is uniform and could be well controlled. One or few breeding units can then distribute breeding animals for a wider use in production herds.

The high genetic correlation (0.99) between PRW and PSW indicates that selection for the PRW will improve also PSW and thereby selection can be made at an early stage of age. The genetic and phenotypic parameters obtained in this study can be used in a breeding scheme and in the construction of selection index. However, it will be necessary to study the maternal effect and its relationship with 
the direct effect and the correlations between milk and growth traits. This study gives clear indications about the good potential to improve the milk production of does or in other words about the maternal component in the early growth of kids. The overall index for meat production would then be made of weight gain and milk production (or maternal component).

If we are interested in the milk production itself, the relatively high estimate of heritability of TMY indicates that selection for this trait is most likely effective. The 90 days yield seems to a good genetic predictor for the total milk yield. When the selection on growth traits can be done very early, it is possible to synchronize the selection scheme for milk production with this by using the 90 days milk records.

There were also some suggestions in the results that substantial variation exists in the shape of lactation curve. Therefore before any genetic improvement is founded for a dairy type Zaraibi goat, we need more information on the genetic variation in lactation curve parameters. The current recording frequency is sufficient for carrying such an analysis.

\section{REFERENCES}

Abdel-Monaam A.U., 1986. Studies on milk yield of Egyptian Nubian goats. M.Sc. Thesis, Faculty of Agriculture, Cairo University, Giza, Egypt. pp. 88

Abdel-Raheem, A.A., 1998. Genetic studies on Zaraibi goats. Ph.D.thesis, Fac. of Agric, Ain Shams, Univ., Egypt, pp. 38-55.

Al-Shorepy, S.A., G.A. Alhadrami and K. Abdelwahab, 2002. Genetic and phenotypic parameters for early growth traits in Emirati goat. Small Rumin. Res. 45:217-223.

Analla, M., I. Jimenez-Gamero, A. Munoz-Serrano, J.M. Serradillo, and A. Falagans, 1995. Estimation of genetic parameters for milk yield and protein contents of milk from Murciano-Granadina goats. J. Dairy Sci. 79:1895-1898.

Bata, S.S., 1989. Phenotypic and genetic parameters of some productive traits of Zaraibi goats. Ph. D. thesis, Faculty of Agric., Al-Azhar, Univ., Egypt, pp. 67174.

Boldman, K.G., L.A. Kriese, L.D. Van Velck, C.P. Van Tassell, and S.D. Kachman, 1995. A Manual for Use of MTDFREML. A set of programs to obtain estimates of variances and covariances. [DRAFT].U.S. Department of Agriculture, Agricultural Research Service, Clay Center, NE. pp. 120.

Constantinou, A., 1989. Genetic and environmental relationships of body weight, milk yield and litter size in Damascus goats. Small Rumin. Res. 2: 163:174.

Constantinou, A. and A.P. Mavrogenis, 1987. Nucleus flock selection strategies for the simultaneous improvement of kid growth and milk yield. Int. National Conf. on Anim. Prod. in Arid Zones (ICARZ). Proceedings of a Conf., Damascus, Syria, 7-12 Sep. 1985. Part2, 615-637. Damascus, Syria, Arab Center for the Studies of Arid Zones and Dry Lands (ACSAD). A. B. A. 1990. 05800179.

Constantinou, A., R. Beuing and A.P. Mavrogenis, 1985. Genetic and phenotypic parameters for some reproduction and milk production characters of the Damascus goat. Zeitschrift fur Tierzuchtung und Zuchtungsbiologie 102:301-307.

Devendra, C., and G.M. Mcleroy, 1982. Goat and Sheep Production in the Tropics. $\left(1^{\text {st }}\right.$. Ed) Longman Group Ltd., London, pp. 271. 
Eissa, M., 1996. Improving productivity of Desert Barki goats by crossing with Damascus goats with special reference to milk production. Ph. D. Thesis, Fac. of Agric. Alex, Univ. Egypt, pp. 53-124.

El-Saied. U.M., J.A. Carriedo, J.A. Baro, L.F. De Le Fuente and F. San Primitivo, 1998. Genetic correlations and heritabilities for milk yield and lactation length of dairy sheep. Small Rumin. Res. 27: 217-221.

Falconer, D.S. and T.F.C., Mackay, 1996. Introduction to Quantitative Genetics. $4^{\text {th }}$ edition. Longman, Harlow, Essex, UK.pp . 464.

Galal, S., Ferial Abdel Rasoul, M.R. Anous and I. Shaat, 2005. Small Ruminant Breeds in Egypt. In Iñiguez, Luis. Characterization of Small Ruminant Breeds in West Asia and North Africa. Vol 2. North Africa . International Center for Agricultural Research in the Dry Land (ICARDA), Aleppo, Syria, pp. 140-193.

Gall, C., 1981. Goat Production .Academic press, London, New York, pp. 619.

Garcia, B.O., B.E. Garcia, P.J. Bravo and B. Kennedy, 1985. Genetic improvement of Criollo goats in Venezuella by means of crossbreeding with imported breeds. Growth of kids and milk yield. Memorias, Asociaion. Latinoamericana. De. Production. Anim. 18: 154, 156.

Graser, H.U., S.P. Smith and B. Tier, 1987. A derivative-free approach for estimating variance components in animal models by restricted maximum likelihood. J. Anim. Sci. 64:1362-1370.

Grossman. M., R.L., Fernando, W.A., Mohammad, A.K.A., Ali and R.D., Shanks, 1986. Correlations between parities for lactation traits in United States dairy goats. J. Dairy. Sci. 69:1917-1921.

Hermiz, H.N., H.J., Al-Amily and E.A., Assak, 1997. Some genetic and non-genetic parameters for pre-weaning growth traits in Angora goats. Dirasat. Agric. Res. Sci. 24: 182-186.

Iloeje, M.U., L.D. Van Vleck and G.R. Wiggans, 1981. Components of variance for milk and fat yields in dairy goats. J. Dairy. Sci. 64: 2290-2293.

Kominakis, A., E. Rogdakis, CH. Vasiloudis and O. Liaskos, 2000. Genetic and environmental sources of variation of milk yield of Skopelos dairy goats. Small Rumin. Res. 36: 1-5.

Lidauar, M., E.A. Mantysaari and I. Stranden, 2003. Comparison of test-day models for genetic evaluation of production traits in dairy cattle. Livestock Prod. Sci. 79: 73-86.

Mavrogenis, A.P., A. Constantinou and A. Louca, 1984. Environmental and genetic causes of variation in production traits of Damascus goats. Anim. Prod. 38:99104.

Medeiros, L.P., R.N. Girao, E.S. Girao, S.C. Pimentel, V.O. Ribeiro, L. Pinto R. Medeiros, Nonato Girao, E. Santiago, J.C. Mashado, V. Pimentel and Queiroz Ribeiro, 1993. Production of Morato goats in Piani state. Ciencia Rural., 32: 357362.

Mekkawy, W.A., 2000. Estimation of genetic parameters for growth performance of Zaraibi goats. M. Sc. Thesis, Faculty of Agric., Ain Shams univ., Egypt, pp. 2149.

Mourad, M. and M.R. Anous, 1991. Effect of herd importation on reproductive and growth traits of Alpine goats in Egypt. Egypt. J. Anim. Prod. 28: 169-178. 
Mourad, M., 2001. Estimation of repeatability of milk yield and reproductive traits of Alpine goats under an intensive system of production in Egypt. Small Rumin. Res. 42:1-4.

Portolano, B., L. Montalbano and W. Militi, 2001. Genetic and environmental sources of variation for milk yield traits in Barbaresca Siciliana breed. Small Rumin. Res. 41: 195-202.

Rabasco, A., J.M. Serradilla, J.A. Padilla and A. Serrano, 1993. Genetic and nongenetic sources of variation in yield and composition of milk in Verata goats. Small Rumin. Res. 11: 151-161.

Shaat, I., L. Varona and W. Mekkawey, 2005. Multiple trait Bayesian analysis of birth, weaning and yearling body weights of Egyptian Zaraibi goat. Book of the abstract for the $56^{\text {th }}$ Annual Meeting of the EAAP, Uppsala, Sweden. 5-8 June, 2005

Singh, D.K., 1997. Genetic studies on post-weaning body weights of Black Bengal and its halfbreds with Jamunapari and Beetal goats. J. Indian. Anim. Sci. 67:1015-1017. 


\section{تقديرات المكافئ الوراثي والارتباط لصفات اللبن والنمو في الماعز الزاريبي}

إيهاب شعت1، منير مبروك'، عبد الفتاح عبدا لحكيم عبدا لرحيم، عادل حامد1

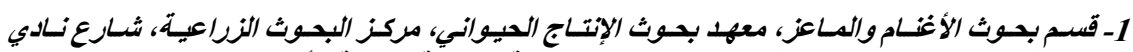
الصيد،/لاقي، القاهزة، مصر، 2- قسم الإنتاج الحيواني، كلية النراعة، جامعة الأزهر

إسثخدم في هذه الدراسة سجلات من محطة السرو التابعة لمعهد بحوث الإنتاج الحيو اني وذلك لتقدير المقاييس

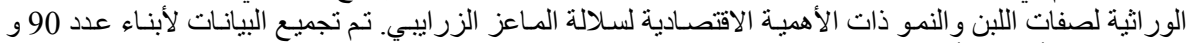

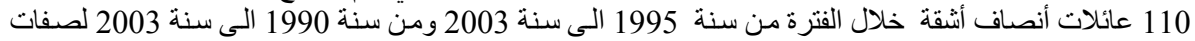

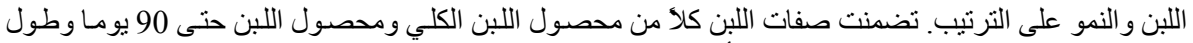

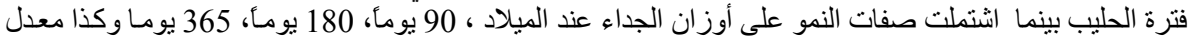

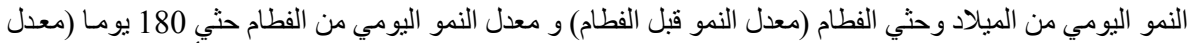

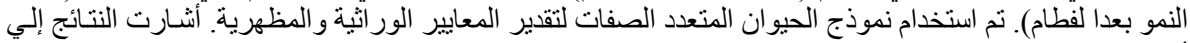

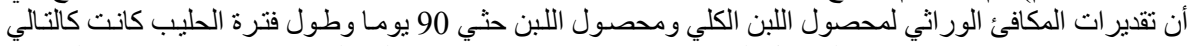

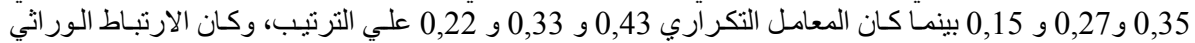

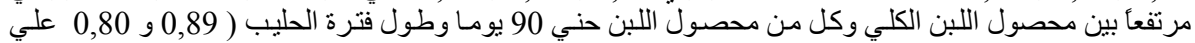

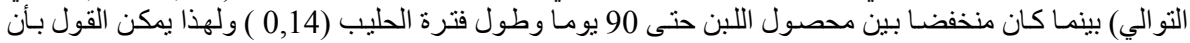

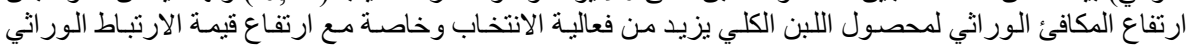

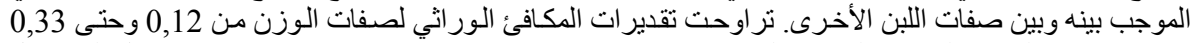

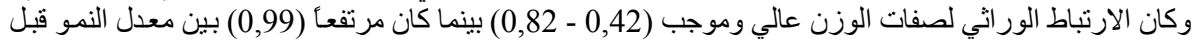
الفطام وبعده، وهذا الارنباط الور اثي العالي يجعل الانتخاب المبكر لمعدل النمو قبل الفطام يحسن من صفة معدل النمو لئن 